\title{
Biology of Corythucha gossypii Fabricius, 1794 (Hemiptera: Tingidae) in Ricinus communis at different temperatures and thermal requirements
}

\author{
S. R. Oliveira ${ }^{a}$, C. A. D. Silva ${ }^{a, b *}$, T. S. Carvalho and L. A. A. Costa ${ }^{a}$ \\ aPrograma de Pós-graduação em Ciências Agrárias, Universidade Estadual da Paraíba - UEPB, Rua Domitila Cabral de \\ Castro, s/n, Bairro Universitário (Bodocongó), CEP 58429-570, Campina Grande, PB, Brasil \\ bLaboratório de Entomologia, Centro Nacional de Pesquisa de Algodão, Empresa Brasileira de Pesquisa Agropecuária - \\ EMBRAPA, Rua Osvaldo Cruz, 1143, Centenário, CEP 58107-720, Campina Grande, PB, Brasil \\ 'Departamento de Entomologia, Museu Nacional, Universidade Federal do Rio de Janeiro - UFRJ, Quinta da Boa Vista, \\ São Cristóvão, CEP 20940-040, Rio de Janeiro, RJ, Brasil \\ *e-mail: carlos.domingues-silva@embrapa.br
}

Received: May 25, 2017 - Accepted: November 6, 2017 - Distributed: May 31, 2019

(With 1 figure)

\begin{abstract}
We studied the biology of Corythucha gossypii in Ricinus communis under different temperatures in climatic chambers adjusted at $20,23,25$, and $28{ }^{\circ} \mathrm{C}, 60 \pm 10 \%$ relative humidity, and a 12 -h photoperiod. The development period and viability of eggs, the development period and survival rate of nymphs, and egg-adult cycle of $C$. gossypii as well as the adult longevity and fecundity were estimated. The thermal requirements $(\mathrm{K})$ and temperature-base $(\mathrm{Tb})$ were estimated for each of the immature stages and for the eggs-adults period. The duration of the eggs and nymphs phases and the egg-adult cycle of the $C$. gossypii on castor bean leaves at $20-28^{\circ} \mathrm{C}$ were $7.6-17$ days, $10.2-27.5$ days, and 16.9-44.5 days, respectively. The lower temperature inhibited the oviposition of $C$. gossypii, whereas the higher temperatures were most favorable for its development. The municipalities of the Bahia state of Brumado, Irecê, Itaberaba, Jacobina, and Senhor do Bonfim were estimated to have a high potential for the population growth of C. gossypii. However, a greater number of generations per year of C. gossypii were observed in the municipalities of Brumado and Itaberaba.
\end{abstract}

Keywords: castor bean, development time, lace bug, thermal threshold.

\section{Biologia de Corythucha gossypii Fabricius, 1794 (Hemiptera: Tingidae) em Ricinus communis em diferentes temperaturas e exigências térmicas}

\begin{abstract}
Resumo
Estudamos a biologia de Corythucha gossypii em Ricinus communis sob diferentes temperaturas em câmaras climatizadas ajustadas as temperaturas de $20,23,25$ e $28^{\circ} \mathrm{C}$, umidade relativa de $60 \pm 10 \%$ e fotoperíodo de 12 horas. O período de desenvolvimento e a viabilidade dos ovos, o período de desenvolvimento e a taxa de sobrevivência de ninfas e do ciclo de ovo-adulto de C. gossypii, bem como a longevidade dos adultos e fecundidade foram estimados. As exigências térmicas $(\mathrm{K})$ e as temperaturas-bases $(\mathrm{Tb})$ foram estimadas para cada um dos estádios imaturos e para o ciclo de ovo-adulto. A duração das fases de ovos e ninfas e do ciclo de ovo a adulto de C. gossypii em folhas de mamona a $20-28^{\circ} \mathrm{C}$ foram de 7,6-17 dias, 10,2-27,5 dias e 16,9-44,5 dias, respectivamente. A temperatura mais baixa inibiu a oviposição de $C$. gossypii, enquanto as temperaturas mais altas foram favoráveis ao seu desenvolvimento. Os municípios do estado da Bahia de Brumado, Irecê, Itaberaba, Jacobina e Senhor do Bonfim foram estimados para ter um alto potencial para o crescimento populacional de C. gossypii. No entanto, o maior número de gerações por ano de C. gossypii foi observado nos municípios de Brumado e Itaberaba.
\end{abstract}

Palavras-chave: mamona, tempo de desenvolvimento, percevejo de renda, limiar térmico.

\section{Introduction}

Brazil is the world's third-largest producer of castor bean (Ricinus communis L., Malpighiales: Euphorbiaceae) after China and India. The estimated castor production for 2015-2016 harvest in Brazil was 97,300 tons in 125,100-ha area, representing $52.4 \%$ growth in the national acreage as compared to the data from the previous year (CONAB, 2016). The northeast region comprises of $>99 \%$ of the planted area, with a production of 96,800 tons in the 
2015-2016 crop season. Among the states of this region, Bahia stands out with a production of around 95,000 tons, which accounted for over $98 \%$ of the castor oil production in Brazil (Costa et al., 2014).

Castor bean is highly adapted to the Brazilian soil and climatic conditions, especially in the semiarid region (Corrêa et al., 2006). In the northeast region, for example, planting this crop has been encouraged not only due to the low cost of implementation and production involved but also for its recognized tolerance to adverse conditions of climate and soil, such as in drought-related stress area (Severino et al., 2012). Nevertheless, the crop yield in Brazil is lower than in other countries due to the lack of information about the damages caused by species of insects and mites, which has compromised the economic exploitation of this crop (Ribeiro and Costa, 2008). Some species of Tingidae (Hemiptera, Heteroptera) have a great potential to become the major pests of this crop, among them, Corythucha gossypii (Fabricius, 1794) is notable (Varón et al., 2010).

Adults and nymphs of the lace bug C. gossypii feed on both sides of the castor bean leaves, causing injuries similar to the ones caused by other tingids. The damage is initially characterized by the formation of white punctuation that progresses to tanning, chlorosis, and, eventually, to premature dropping of the leaves (Li et al., 2007).

Temperature is a determining factor in the geographical distribution of species (Calosi et al., 2010; Kellermann et al., 2012a, b; Overgaard et al., 2014), particularly the metabolic activity and development time of insects (Damos and Savopoulou-Soultani, 2011; Pereira et al., 2011; Poncio et al., 2016). However, to understand the effect of temperature on the life cycle of insects, it is necessary to determine the base temperature and thermal constant of these arthropods (Damos and Savopoulou-Soultani, 2008, 2011). Therefore, the information on the thermal requirements in the development of insect pests have important implications in the control programs of such organisms, because the temperature determines the growth and size of the pest population and its variation in different environmental conditions. Thus, the insight to this information would provide support for the prediction of population dynamics and spatial and seasonal distributions of these organisms in the main castor-producing regions of Brazil.

In this study, we evaluated the biology of the lace bug C. gossypii in castor beans under different temperatures.

\section{Material and Methods}

\subsection{Insects and plant}

This study was conducted in the Laboratory of Entomology, Embrapa Cotton, Campina Grande, Paraíba, and Brazil (7¹3'50'S, 35 52'52'”W).

The specimens of castor bean cultivar "BRS Paraguaçú" were first planted in 4-L-plastic pots filled with soil collected from the experimental field, which was classified as a mixture of entisol eutrophic and manure (3:1 ratio), as recommended by the Soils Laboratory of the Embrapa
Cotton. The plants were kept in the greenhouse until 55 days of age and then transferred to the laboratory for evaluate tingids infestation.

The C. gossypii specimens used in the experiment were collected from castor bean plants attacked in the Embrapa Cotton field. A total of 30 specimens ( 20 females and 10 males) of the lace bugs were collected using a brush, transferred to dry glass jars, and sent to Dr. Luiz Antônio Alves Costa (National Museum of the Federal University of Rio de Janeiro in Rio de Janeiro State, Brazil) for identification. These specimens were identified based almost exclusively on external morphology, because genital traits are not usually described (Monte, 1941) and deposited at the National Museum. For each temperature condition, two leaves of a castor plant were infested with 40 C. gossypii females, which continued laying eggs for $24 \mathrm{~h}$. The infested leaves were wrapped with voile to prevent the insects' escape. At the end of this period, the females were removed and their positions were marked with black paint to facilitate stereoscopic microscope inspections until the emergence of the nymphs.

\subsection{Biology and thermal time bioassays}

A castor bean plant containing 250 newly laid eggs inside the leaves by $C$. gossypii females were maintained in the biochemical oxygen demand (BOD) chambers adjusted at $20,23,25$, and $28^{\circ} \mathrm{C}$ under a relative humidity of $60 \pm 10 \%$ for a 12 -h photoperiod. The eggs were observed daily. The total number of eggs hatched at each temperature and the duration of each egg development (incubation period) was recorded.

To evaluate the nymphal stage at each temperature, the newly emerged first-instar nymphs were kept individually in rearing units consisting of $25-\mathrm{mL}$, transparent, plastic containers $(3 \times 4 \mathrm{~cm})$. Inside these units, a filter paper disk measuring $3.0 \mathrm{~cm}$ in diameter was placed and moistened with distilled water. On this disk, a disk of a castor bean leaf was placed, with the ventral side facing upward. Then, the rearing units were covered with a transparent plastic film and maintained at a given temperature until the insects emerged as adults. The castor bean leaf disks were replaced every 2 days, and the filter paper was moistened on a daily basis.

The development time and viability of eggs and the survival of nymphs and adults of $C$. gossypii as well as the adult longevity and fecundity were estimated. The longevity of males and females was determined by considering the couples. To determine the fertility and the sex ratio of the offspring at each temperature condition, the adults were divided into couples, and the newly emerged males were transferred separately to new arenas containing newly emerged female. The eggs laid in these areas were quantified daily by two observations made at 08:00 AM and 04:00 PM.

\subsection{Data analysis}

The differences in the development periods between C. gossypii males and females were compared by $\mathrm{F}$ test at $5 \%$ probability using the System of Statistical Analysis and 
Genetics (SAEG) (Ribeiro Júnior, 2001). The threshold temperature $(T b)$ and thermal constant $(K)$ were estimated by the hyperbole method (Haddad et al., 1999) based on the duration of the immature stages and the life cycle (egg-adult) of $C$. gossypii. The annual accumulation of degree-days and the likely number of generations $(N G)$ of the lace bug in five castor-producing municipalities of Bahia state were calculated based on the thermal constant (Wilson and Barnett, 1983). The NG was calculated using the following Equation 1:

$N G=T(T m-T b) / K$

where: $K=$ thermal constant; $T m=$ average temperature for each location studied; $T b=$ lower temperature threshold; and $T=$ time (in days).

\section{Results}

The insect was identified as $C$. gossypii (Figures 1A-C).

The viability of $C$. gossypii eggs in castor bean leaves did not vary between the four studied temperatures (Table 1); however, the survival of the nymphal phase ranged from $26 \%$ to $60 \%$. The maximum survival was observed at $25{ }^{\circ} \mathrm{C}$ and the minimum at $20^{\circ} \mathrm{C}$. Among the nymphal instars, the survival rates for the first, second, third, fourth, and fifth instars for the four temperatures studied were $50-82 \%, 75.6-100 \%, 76.5-89.2 \%, 76.9-93.8 \%$, and $80-100 \%$, respectively (Table 2 ).

The developmental time of eggs and nymphs phases, and the egg-adult cycle of $C$. gossypii with castor bean leaves gradually decreased with the increase in the temperature (Table 1), but did not differ between the sexes. The incubation periods of eggs and development period of the nymphal phase and egg-adult cycle were 7.6-17 days, 10.2-27.5 days, and 16.9-44.5 days, respectively, at $20-28{ }^{\circ} \mathrm{C}$.

The development time of the nymphal phase of $C$. gossypii in castor bean leaves varied within each instar stage and between the instars and sexes (Table 2), according to the

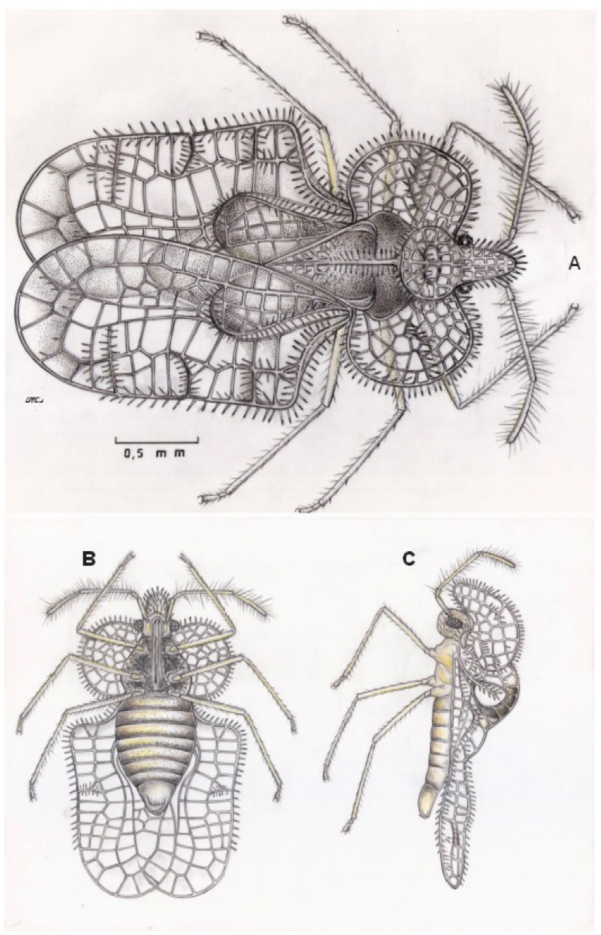

Figure 1. Adult cotton lace bug, Corythucha gossypii (Fabricius, 1794) (Heteroptera: Tingidae) in dorsal (A), ventral (B) and lateral view (C).

Table 1. Survival and development time of the egg and nymph phases and egg-adult cycle of Corythucha gossypii (Hemiptera: Tingidae) with castor leaves at temperatures $20{ }^{\circ} \mathrm{C}, 23{ }^{\circ} \mathrm{C}, 25{ }^{\circ} \mathrm{C}$ and $28{ }^{\circ} \mathrm{C}$, relative humidity of $60 \pm 10 \%$ and photophase of 12 hours.

\begin{tabular}{|c|c|c|c|c|c|c|c|c|c|}
\hline \multirow{2}{*}{ Stage/ cycle } & \multirow{2}{*}{$\begin{array}{c}\text { Temp. } \\
\left({ }^{\circ} \mathrm{C}\right)\end{array}$} & \multirow{2}{*}{ Ind. } & \multirow{2}{*}{$\begin{array}{l}\text { Sur. } \\
(\%)\end{array}$} & \multicolumn{6}{|c|}{ Development time (days) $\pm \mathrm{SE}$} \\
\hline & & & & Female & $(\mathbf{N})$ & Male & (N) & Female + Male & $(\mathbf{N})$ \\
\hline \multirow[t]{4}{*}{ Egg } & 20 & 50 & 100 & $17.38 \pm 0.43$ & 4 & $16.67 \pm 0.17^{\mathrm{N} . \mathrm{S}}$ & 3 & $17.03 \pm 0.28$ & 7 \\
\hline & 23 & 50 & 100 & $10.95 \pm 0.05$ & 11 & $11.00 \pm 0.00^{\mathrm{N} . \mathrm{S}}$ & 8 & $10.97 \pm 0.03$ & 19 \\
\hline & 25 & 50 & 100 & $9.13 \pm 0.06$ & 15 & $9.43 \pm 0.13^{\mathrm{N} . \mathrm{S}}$ & 15 & $9.28 \pm 0.07$ & 30 \\
\hline & 28 & 50 & 100 & $7.33 \pm 0.17$ & 5 & $7.80 \pm 0.20^{\mathrm{N} . \mathrm{S}}$ & 9 & $7.57 \pm 0.16$ & 14 \\
\hline \multirow[t]{4}{*}{ Nymph } & 20 & 13 & 26 & $27.13 \pm 0.80$ & 4 & $27.83 \pm 0.60^{\mathrm{N} . \mathrm{S}}$ & 3 & $27.48 \pm 0.51$ & 7 \\
\hline & 23 & 19 & 38 & $16.77 \pm 0.40$ & 11 & $17.13 \pm 0.51^{\mathrm{N} . \mathrm{S}}$ & 8 & $17.05 \pm 0.31$ & 19 \\
\hline & 25 & 30 & 60 & $11.13 \pm 0.16$ & 15 & $11.47 \pm 0.14^{\mathrm{N} . \mathrm{S}}$ & 15 & $11.30 \pm 0.11$ & 30 \\
\hline & 28 & 16 & 32 & $9.83 \pm 0.60$ & 5 & $10.60 \pm 0.51^{\mathrm{N} . \mathrm{S}}$ & 9 & $10.22 \pm 0.20$ & 14 \\
\hline \multirow[t]{4}{*}{ Egg-adult } & 20 & 13 & 100 & $44.50 \pm 0.96$ & 4 & $44.50 \pm 0.50^{\mathrm{N} . \mathrm{S}}$ & 3 & $44.50 \pm 0.55$ & 7 \\
\hline & 23 & 19 & 100 & $27.73 \pm 0.39$ & 11 & $28.13 \pm 0.51^{\mathrm{N} . \mathrm{S}}$ & 8 & $27.93 \pm 0.30$ & 19 \\
\hline & 25 & 30 & 100 & $20.27 \pm 0.16$ & 15 & $20.90 \pm 0.22^{\mathrm{N} . \mathrm{S}}$ & 15 & $20.58 \pm 0.15$ & 30 \\
\hline & 28 & 16 & 100 & $16.80 \pm 0.30$ & 5 & $16.94 \pm 0.27^{\mathrm{N} . \mathrm{S}}$ & 9 & $16.87 \pm 0.20$ & 14 \\
\hline
\end{tabular}

$\mathrm{N} . \mathrm{S}=$ Not significant for the duration of development between female and male by $\mathrm{F}$ test $(\mathrm{P}=0.05)$; Temp $=$ temperature; Ind = number of individuals per instar at each temperature; Sur = Suvival; SE = standard error; $N=$ number of individuals that achieved the adult stage. 
Table 2. Survival and development time (day, mean \pm standard error) of nymphs in the different instar of Corytucha gossypii in castor leaves, at $20^{\circ} \mathrm{C}, 23{ }^{\circ} \mathrm{C}, 25^{\circ} \mathrm{C}$ and $28^{\circ} \mathrm{C}$, relative humidity of $60 \pm 10 \%$ and photophase of 12 hours.

\begin{tabular}{|c|c|c|c|c|c|c|c|}
\hline \multirow{2}{*}{$\begin{array}{l}\text { Nymphal } \\
\text { stage }\end{array}$} & \multirow{2}{*}{$\begin{array}{c}\text { Temp. } \\
\left({ }^{\circ} \mathrm{C}\right)\end{array}$} & \multirow{2}{*}{ Ind. } & \multirow{2}{*}{$\begin{array}{l}\text { Sur. } \\
(\%)\end{array}$} & \multicolumn{4}{|c|}{ Development time (days) \pm standard error } \\
\hline & & & & Fêmea & $(\mathbf{N})$ & Macho & $(\mathbf{N})$ \\
\hline \multirow[t]{4}{*}{1 st instar } & 20 & 25 & 50.00 & $6.75 \pm 0.66$ & 4 & $6.83 \pm 0.73^{\mathrm{N} . \mathrm{S}}$ & 3 \\
\hline & 23 & 41 & 82.00 & $2.86 \pm 0.20$ & 11 & $3.13 \pm 0.26^{\mathrm{N} . \mathrm{S}}$ & 8 \\
\hline & 25 & 37 & 74.00 & $2.67 \pm 0.06$ & 15 & $2.57 \pm 0.05^{\mathrm{N} . \mathrm{S}}$ & 15 \\
\hline & 28 & 40 & 80.00 & $2.00 \pm 0.00$ & 5 & $2.17 \pm 0.17^{\mathrm{N} . S}$ & 9 \\
\hline \multirow[t]{4}{*}{ 2nd instar } & 20 & 19 & 76.00 & $3.50 \pm 0.29$ & 4 & $5.00 \pm 0.20^{*}$ & 3 \\
\hline & 23 & 31 & 75.61 & $2.56 \pm 0.26$ & 11 & $2.41 \pm 0.16^{\mathrm{N} . \mathrm{S}}$ & 8 \\
\hline & 25 & 37 & 100.00 & $1.63 \pm 0.06$ & 15 & $1.63 \pm 0.06^{\mathrm{N} . \mathrm{S}}$ & 15 \\
\hline & 28 & 34 & 85.00 & $1.50 \pm 0.00$ & 5 & $1.44 \pm 0.10^{\mathrm{N} . \mathrm{S}}$ & 9 \\
\hline \multirow[t]{4}{*}{ 3rd instar } & 20 & 16 & 84.21 & $4.25 \pm 0.14$ & 4 & $5.67 \pm 0.33^{*}$ & 3 \\
\hline & 23 & 24 & 77.42 & $3.50 \pm 0.31$ & 11 & $3.14 \pm 0.14^{\mathrm{N} . \mathrm{S}}$ & 8 \\
\hline & 25 & 33 & 89.19 & $1.80 \pm 0.07$ & 15 & $1.63 \pm 0.06^{\mathrm{N} . \mathrm{S}}$ & 15 \\
\hline & 28 & 26 & 76.47 & $1.50 \pm 0.12$ & 5 & $1.50 \pm 0.00^{\mathrm{N} . \mathrm{S}}$ & 9 \\
\hline \multirow[t]{4}{*}{ 4th instar } & 20 & 15 & 93.75 & $5.63 \pm 0.38$ & 4 & $5.00 \pm 0.50^{\mathrm{N} . \mathrm{S}}$ & 3 \\
\hline & 23 & 21 & 87.50 & $3.86 \pm 0.21$ & 11 & $3.88 \pm 0.31^{\mathrm{N} . \mathrm{S}}$ & 8 \\
\hline & 25 & 30 & 90.91 & $2.03 \pm 0.08$ & 15 & $2.20 \pm 0.07^{\mathrm{N} . \mathrm{S}}$ & 15 \\
\hline & 28 & 20 & 76.92 & $2.20 \pm 0.20$ & 5 & $2.11 \pm 0.25^{\mathrm{N} . \mathrm{S}}$ & 9 \\
\hline \multirow[t]{4}{*}{5 th instar } & 20 & 13 & 86.67 & $5.50 \pm 0.20$ & 4 & $6.83 \pm 0.67^{\mathrm{N} . \mathrm{S}}$ & 3 \\
\hline & 23 & 19 & 90.48 & $4.50 \pm 0.28$ & 11 & $4.06 \pm 0.11^{\mathrm{N} . \mathrm{S}}$ & 8 \\
\hline & 25 & 30 & 100.00 & $3.17 \pm 0.14$ & 15 & $3.27 \pm 0.10^{\mathrm{N} . \mathrm{S}}$ & 15 \\
\hline & 28 & 16 & 80.00 & $3.10 \pm 0.10$ & 5 & $3.22 \pm 0.24^{\mathrm{N} . \mathrm{S}}$ & 9 \\
\hline
\end{tabular}

N.S $=$ Not significant and *significant for the duration of development between female and male by $\mathrm{F}$ test $(\mathrm{P}=0.05)$; Temp = temperature; Ind = number of individuals per instar at each temperature; Sur = Suvival; N = number of individuals that achieved the adult stage.

Table 3. Longevity (day, mean \pm standard error) and fecundity (total eggs, mean \pm standard error) of Corytucha gossypii in castor bean leaves at $20^{\circ} \mathrm{C}, 23{ }^{\circ} \mathrm{C}, 25^{\circ} \mathrm{C}$ and $28{ }^{\circ} \mathrm{C}$, relative humidity of $60 \pm 10 \%$ and photophase of 12 hours.

\begin{tabular}{ccccc}
\hline Temp. $\left({ }^{\circ} \mathbf{C}\right)$ & Sex & $(\mathbf{N})$ & Longevity & Fecundity \\
\hline 20 & Female & 3 & $14.17 \pm 1.48$ & - \\
& Male & 3 & $13.50 \pm 1.00$ & - \\
23 & Female & 6 & $46.82 \pm 2.18$ & $146.33 \pm 31.17$ \\
& Male & 6 & $42.31 \pm 2.54$ & - \\
25 & Female & 6 & $34.53 \pm 1.80$ & $148.00 \pm 32.80$ \\
& Male & 6 & $34.47 \pm 4.16$ & - \\
& Female & 5 & $24.30 \pm 3.61$ & $167.00 \pm 28.00$ \\
\hline
\end{tabular}

$\mathrm{N}=$ individuals number.

temperature. Within each instar, the duration gradually decreased with increasing temperature. On the other hand, longer periods between instars were observed for the fifth-instar nymphs and shorter periods for the second- and third-instar nymphs, except for similar amount of days for the first- and fifth-instar nymphs at $20^{\circ} \mathrm{C}$. Among the second- and third-instar nymphs at $20^{\circ} \mathrm{C}$, the nymphs that originated males showed a longer development time than those that originated females.

The longevity of $C$. gossypii adults in castor bean leaves were 24.3-46.8 days and 21.3-42.3 days for females and males nymphs, respectively (Table 3 ). The greatest longevity period was observed for females nymphs at $23{ }^{\circ} \mathrm{C}$, followed by those kept at $25^{\circ} \mathrm{C}$. The smallest longevity of C. gossypii adults was observed for those kept at $28^{\circ} \mathrm{C}$.

The fecundity of $C$. gossypii in castor bean leaves varied with temperature (Table 3 ), with a better performance demonstrated at higher temperatures. At $20^{\circ} \mathrm{C}$, the females did not lay any eggs. Similarly, the sex ratio in castor bean leaves varied with the temperature, with values of $0.57,0.58$, 0.50 , and 0.38 at temperatures of $20,23,25$, and $28{ }^{\circ} \mathrm{C}$, respectively.

The development rate to the egg and nymph stages and the egg-adult cycle of $C$. gossypii with castor bean leaves 
Table 4. Linear regression equations between the rates of development $r(T)$ and temperature $\left(20{ }^{\circ} \mathrm{C}, 23{ }^{\circ} \mathrm{C}, 25{ }^{\circ} \mathrm{C}\right.$ and $\left.28{ }^{\circ} \mathrm{C}\right)$ to determine the base temperature $(\mathrm{Tb})$ and thermal constant $(K)$ for egg and nymph stages and egg-adult cycle of development of Corytucha gossypii in castor leaves.

\begin{tabular}{cccccccc}
\hline Phase & Instar & $\boldsymbol{T} \boldsymbol{b}\left({ }^{\circ} \mathbf{C}\right)$ & $\boldsymbol{K}$ & $\boldsymbol{a}^{(\mathbf{1})} \pm$ standard error & $\mathbf{b}^{(\mathbf{2})} \pm$ standard error & $\boldsymbol{P r}>\boldsymbol{\chi}^{2}$ & $\boldsymbol{R}^{\mathbf{2}}$ \\
\hline Egg & - & 15.14 & 86.81 & $-0.17446 \pm 0.02121$ & $0.01152 \pm 0.00088$ & 0.0057 & 0.98 \\
& First & 15.26 & 26.70 & $-0.57176 \pm 0.17614$ & $0.03746 \pm 0.00729$ & 0.0358 & 0.89 \\
& Second & 16.74 & 15.90 & $-1.03640 \pm 0.15045$ & $0.06291 \pm 0.00622$ & 0.0096 & 0.97 \\
& Third & 16.95 & 16.15 & $-1.04962 \pm 0.37136$ & $0.06193 \pm 0.01536$ & 0.0564 & 0.84 \\
& Fourth & 15.92 & 23.72 & $-0.67116 \pm 0.28193$ & $0.04215 \pm 0.01166$ & 0.0687 & 0.80 \\
& Fifth & 11.92 & 47.55 & $-0.25070 \pm 0.12738$ & $0.02103 \pm 0.00527$ & 0.0574 & 0.83 \\
Nymphal & - & 15.40 & 123.46 & $-0.12477 \pm 0.03222$ & $0.00810 \pm 0.00133$ & 0.0260 & 0.92 \\
Egg-adult & - & 15.36 & 208.33 & $-0.07375 \pm 0.00866$ & $0.00480 \pm 0.00036$ & 0.0055 & 0.98 \\
\hline
\end{tabular}

${ }^{(1)}$ The base temperature or low development threshold $(T b)$ is calculated as $T b=2 a / b$; (2) The thermal constant, $k$ (day-degrees) is calculated as $k=1 / b . a$ is the intercept, and $\mathrm{b}$ is the regression line slope. The values of $T b$ and $k$ were calculated for each instar and nymph stage (from hatching to the adult stage).

Table 5. Annual accumulation of degree-days and probable number of generations of Corythucha gossypii in five regions with castor bean crops in the State of Bahia, based on the thermal constant ${ }^{(1)}$.

\begin{tabular}{lcc}
\hline Municipality & \multicolumn{2}{c}{ Egg to adult period } \\
\cline { 2 - 3 } & $\begin{array}{c}\text { Annual } \\
\text { degree-days }\end{array}$ & $\begin{array}{c}\text { Number of } \\
\text { generations } \\
\text { per year }\end{array}$ \\
\hline Brumado & 3447.3 & 16.5 \\
Irecê & 3007.3 & 14.4 \\
Itaberaba & 3642.7 & 17.5 \\
Jacobina & 3073.1 & 14.8 \\
Senhor do & 2996.1 & 14.4 \\
Bonfim & & \\
\hline
\end{tabular}

${ }^{(1)}$ The daily maximum and minimum temperatures in the municipalities listed in the table were obtained from the INMET (2016) and used for degree-day calculation for the year 2015 .

showed a linear and positive correlation with temperatures between $20^{\circ} \mathrm{C}$ and $28^{\circ} \mathrm{C}$ (Table 4). Within this temperature range, the second- and third-instar nymphs showed higher development rate, which could be confirmed by larger angular coefficients of the regression equations estimated for these instars.

Thermal constants for the egg and nymph stages and the egg-adult cycle of C. gossypii with castor leaves showed a linear and positive correlation with the temperature of 20-28 ${ }^{\circ} \mathrm{C}$ (Table 4).

The likely number of generations of $C$. gossypii throughout the year in the municipalities of Brumado, Irecê, Itaberaba, Jacobina, and Senhor do Bonfim (the largest castor bean producers in Brazil; Bahia state) ranged from 14.4 to 17.5 (Table 5). The municipalities of Itaberaba and Brumado, two of the hottest cities in the region, possess the greatest potential of annual generations of C. gossypii, while municipalities with cooler temperatures such as Irecê, Jacobina, and Senhor do Bonfim are predicted to yield fewer numbers of generations per year.

\section{Discussion}

The high viability rate of eggs with castor bean leaves is similar to the $>90 \%$ value observed for the viability of C. ciliata eggs (Ju et al., 2011a) in the studied temperature range with hybrid plane leaves of Platanus $\times$ acerifolia (Aiton). This observation can be attributed to $C$. ciliate's oviposition behavior. The females often lay their eggs on both the sides of the leaf and next to the midvein or lateral veins, inserted partially in the leaf parenchyma; this site of oviposition protects the eggs from abiotic stress factors such as water loss and extreme temperatures and biotic ones such as attack by natural enemies (Southwood, 1973).

The shorter incubation period of $C$. gossypii eggs at temperature between $20{ }^{\circ} \mathrm{C}$ and $28{ }^{\circ} \mathrm{C}$ as compared to those of 12-19 days by C. cydoniae on leaves of Crataegus phaenopyrum (L.f.) Medik. (Neal Junior and Douglass, 1990), 11.3-26.5 days by C. cydoniae on leaves of Cotoneaster dammeri (Braman and Pendley, 1993), and 8.8-20 days by $C$. ciliata on hybrid plane leaves (Ju et al., 2011b) can be attributed to differences among the oviposition sites in the plant tissue of the host leaves. The oviposition of $C$. gossypii is endophytic, while those of C. cydoniae and C. ciliata are pseudo-endophytic and exophytic, respectively. In the endophytic posture, the eggs are inserted into the spongy mesophyll with only the operculum left outside the vegetable tissue, while, in the pseudo-endophytic posture, the eggs are partially inserted in the plant tissue. In the exophytic posture, the eggs are deposited on the surface of the plant tissue (Guidoti et al., 2015).

The differences in the development time of the second- and third-instar nymphs of C. gossypii at $20^{\circ} \mathrm{C}$ that originated males and females may be attributed to the reduced number of individuals used to calculate this development period of this lace bug at this temperature. However, the development time of the phases of egg, nymph, and egg-adult did not differ between the sexes at all temperatures, indicating that nymphs at a more advanced instar stage of development can compensate for the possible differences between the sexes in the development time 
of initial instars. The duration time of nymph stage and egg-adult cycle of $C$. gossypii at $20-28{ }^{\circ} \mathrm{C}$ were similar to that of 12.1-29.3 days and 22.8-55.6 days observed for the nymph stage and egg-adult cycle of $C$. cydoniae on the leaves of Cotoneaster dammeri $\left(19-30{ }^{\circ} \mathrm{C}\right)$ (Braman and Pendley, 1993), respectively, and of 11.3-27.6 days and 20.0-47.6 days for the same development period of C. ciliata on the hybrid plane leaves $\left(19-30{ }^{\circ} \mathrm{C}\right)(\mathrm{Ju}$ et al., 2011a). Moreover, the durations were greater, ranging from 14.7 to 23.4 days and 26.6 to 42.5 days for the nymph stage and the egg-adult cycle of $C$. cydoniae on the leaves of Crataegus phaenopyrum (Neal Junior and Douglass, 1990).

The survival rates for the first-, second-, third-, fourth-, and fifth-instars for the four temperatures studied were less than those in survival from $63 \%$ to $90 \%, 95 \%$ to $100 \%$, $96 \%$ to $99 \%, 96 \%$ to $97.5 \%$, and $85 \%$ to $95 \%$ observed for the respective instars of C. ciliata on hybrid plane leaves $\left(19-30{ }^{\circ} \mathrm{C}\right)$. On the other hand, the improved survival of C. gossypii at $25{ }^{\circ} \mathrm{C}$ and its reduction at $20^{\circ} \mathrm{C}$ indicates that these nymph species preferably survive in warmer temperatures.

Variations in the development time of $C$. gossypii within each instar and between instars and sexes according to the temperature confirm that temperature is an important climatic factor that influences the development of these insects. The developmental period gradually decreases with increasing temperature conditions. On the other hand, the longest period observed for the fifth-instar nymphs and shortest for the second- and third-instar nymphs, except for similar durations for the first- and fifth-instar nymphs at $20^{\circ} \mathrm{C}$, are in concordance with the previous results observed for other species of Tingidae (Vogt and McPherson, 1986; Neal Junior and Douglass, 1988, 1990; Braman et al., 1992; Braman and Pendley, 1993; Cividanes et al., 2004; Silva, 2004; Aysal and Kivan, 2008; Ju et al., 2011a; Zhang et al., 2011; Carr and Braman, 2012; Moreira et al., 2013; Sánchez-Ramos et al., 2015), thereby confirming this to be the pattern of development for the nymphal stages of lace bugs, as proposed by Sanchez-Ramos et al. (2015).

In this study, adult longevity and fecundity were prolonged and increased with decreasing temperature. At $25^{\circ} \mathrm{C}$, the life spans of the male and female C. gossypii were found to be similar to the life spans of 33.2 days and 34.7 days for the male and female $C$. ciliate, respectively, on hybrid plane leaves at $26{ }^{\circ} \mathrm{C}$ (Ju et al., 2011a).

The positive linear correlation between the development rate and the temperature and between the thermal constant and the temperature for the egg, nymph, and egg-adult stages of $C$. gossypii at $20-28^{\circ} \mathrm{C}$ indicated the thermophilic nature of Tingidae species. The number of degree-days required for the development of egg and nymph stages and the egg-adult cycle were similar to those observed for the Tingidae species Monosteira unicostata on the leaves of Phyllostachys nigra (Sánchez-Ramos et al., 2015 ) to those observed for Gargaphia torresi on cotton leaves (Silva, 2004) and for C. cydoniae on the leaves of Cotoneaster dammeri (Braman and Pendley, 1993). On the other hand, the number of degree-days required for the three developmental stages were superior to the lower limits of $10.5,10.9$, and $11.2^{\circ} \mathrm{C}$ obtained for the respective stages of $C$. ciliata (Ju et al., 2011a).

The largest number of annual generations estimated for C. gossypii in the warm municipalities of Itaberaba and Brumado as compared to those in the colder municipalities of Irecê, Jacobina, and Senhor do Bonfim indicate that the municipalities of Itaberaba and Brumado are most susceptible to population outbreaks and, consequently, to damage caused by castor bean lace bug.

\section{Conclusion}

From this study, it can be concluded that temperature influences the development time of the egg and nymph stages and the egg-adult cycle as well as the longevity and fecundity of C. gossypii on the leaves of castor beans. The temperatures of $25^{\circ} \mathrm{C}$ and $28{ }^{\circ} \mathrm{C}$ were found to be the most favorable for the development of this lace bug. The study indicated that the municipalities of the Bahia state of Brumado, Irecê, Itaberaba, Jacobina, and Senhor do Bonfim have a greater potential for the population growth of C. gossypii. However, the greater number of generations per year of $C$. gossypii observed in Brumado and Itaberaba indicated that $C$. gossypii has more potential to be a pest in these municipalities.

\section{Acknowledgements}

The authors wish to thank to Instituto Nacional de Meteorologia (INMET) for the availability of the climate data and to the Conselho Nacional de Desenvolvimento Científico e Tecnológico (CNPq) and Coordenação de Aperfeiçoamento de Pessoal de Nível Superior (CAPES) for the financial support to the authors.

\section{References}

AYSAL, T. and KIVAN, M., 2008. Development and population growth of Stephanitis pyri (F.) (Heteroptera: Tingidae) at five temperatures. Journal of Pest Science, vol. 81, no. 3, pp. 135-141. http://dx.doi.org/10.1007/s10340-008-0198-9.

BRAMAN, S.K. and PENDLEY, A.F., 1993. Temperature, photoperiod, and agregation effects on development, diapause, reproduction, and survival in Corythuch a cydoniae (Heteroptera: Tingidae). Journal of Entomological Science, vol. 28, no. 4, pp. 417-426. http://dx.doi.org/10.18474/0749-8004-28.4.417.

BRAMAN, S.K., PENDLEY, A.F., SPARKS, B. and HUDSON, W.G., 1992. Thermal requirements for development, popultion trends, and parasitism of azalea lace bug (Heteroptera: Tingidae). Journal of Economic Entomology, vol. 85, no. 3, pp. 870-877. http://dx.doi.org/10.1093/jee/85.3.870.

CALOSI, P., BILTON, D.T., SPICER, J.I., VOTIER, S.C. and ATFIELD, A., 2010. What determines a species' geographical range? Thermal biology and latitudinal range size relationships in European diving beetles (Coleoptera: Dytiscidae). Journal of Animal Ecology, vol. 79, no. 1, pp. 194-204. http://dx.doi. org/10.1111/j.1365-2656.2009.01611.x. PMid:19761459. 
CARR, E.R. and BRAMAN, S.K., 2012. Phenology, abundance, plant injury and effect of temperature on the development and survival of Leptodictya plana (Hemiptera: Tingidae) on Pennisetum spp. grasses. Journal of Entomological Science, vol. 47, no. 2, pp. 131-138. http://dx.doi.org/10.18474/0749-8004-47.2.131.

CIVIDANES, F.J., FONSECA, F.S. and GALLI, J.C., 2004. Biologia de Leptopharsa heveae Drake \& Poor (Heteroptera: Tingidae) e a relação de suas exigências térmicas com a flutuação populacional em seringueira. Neotropical Entomology, vol. 33, no. 6, pp. 685691. http://dx.doi.org/10.1590/S1519-566X2004000600005.

COMPANHIA NACIONAL DE ABASTECIMENTO - CONAB, 2016 [viewed 5 February 2016]. Mamona: série histórica [online]. Brasília: CONAB. Available from: http://www.conab.gov.br

CORRÊA, M.L.P., TÁVORA, F.J.A.F. and PITOMPEIRA, J.B., 2006. Comportamento de cultivares de mamona em plantio consorciadas com caupi e sorgo granífero. Revista Ciência Agronômica, vol. 37, no. 2, pp. 200-207.

COSTA, A.G.F., SOFIATTI, V., MACIEL, C.D.G., POLETINE, J.P. and SOUSA, J.I., 2014. Weed management strategies for castor bean crops. Acta Scientiarum, Agronomy, vol. 36, no. 2, pp. 135-145. http://dx.doi.org/10.4025/actasciagron.v36i2.17090.

DAMOS, P.T. and SAVOPOULOU-SOULTANI, M., 2008. Temperature-dependent bionomics and modeling of Anarsia lineatella (Lepidoptera: Gelechiidae) in the laboratory. Journal of Economic Entomology, vol. 101, no. 5, pp. 1557-1567. http:// dx.doi.org/10.1093/jee/101.5.1557. PMid:18950037.

DAMOS, P.T. and SAVOPOULOU-SOULTANI, M., 2011. Temperature-driven models for insect development and vital thermal requirements. Psyche, vol. 2012, pp. 1-13. http://dx.doi. org/10.1155/2012/123405.

GUIDOTI, M., MONTEMAYOR, S.I. and GUILBERT, E., 2015. Lace bugs (Tingidae). In: R. PANIZZI and J. GRAZIA, eds., True bugs (Heteroptera) of the neotropics. Dordrecht: Springer, pp. 395-422. http://dx.doi.org/10.1007/978-94-017-9861-7_14.

HADDAD, M.L., PARRA, J.R.P. and MORAES, R.C.B., 1999. Métodos para estimar os limites térmicos inferior e superior de desenvolvimento de insetos. Piracicaba: FEALQ, 29 p.

INSTITUTO NACIONAL DE METEOROLOGIA - INMET, 2016 [viewed 23 April 2016]. Dados meteorológicos [online]. Brasília: INMET. Available from: http://www.inmet.gov.br

JU, R.T., CHEN, G.B., WANG, F. and LI, B., 2011a. Effects of heat shock, heat exposure pattern, and heat hardening on survival of the sycamore lace bug, Corythucha ciliata. Entomologia Experimentalis et Applicata, vol. 141, no. 2, pp. 168-177. http:// dx.doi.org/10.1111/j.1570-7458.2011.01180.x.

JU, R.T., WANG, F. and LI, B., 2011b. Effects of temperature on the development and population growth of the sycamore lace bug, Corythucha ciliata. Journal of Insect Science, vol. 11, no. 16, pp. 1-12. http://dx.doi.org/10.1673/031.011.0116. PMid:21526932.

KELLERMANN, V., LOESCHCKE, V., HOFFMANN, A.A., KRISTENSEN, T.N., FLOJGAARD, C., DAVID, J.R., SVENNING, J.-C. and OVERGAARD, J., 2012a. Phylogenetic constraints in key functional traits behind species' climate niches: patterns of desiccation and cold resistance across 95 drosophila species. Evolution, vol. 66, no. 11, pp. 3377-3389. http://dx.doi. org/10.1111/j.1558-5646.2012.01685.x. PMid:23106704.

KELLERMANN, V., OVERGAARD, J., HOFFMANN, A.A., FLOJGAARD, C., SVENNING, J.-C. and LOESCHCKE, V., 2012b. Upper thermal limits of Drosophila are linked to species distributions and strongly constrained phylogenetically. Proceedings of the National Academy of Sciences of the United States of America, vol. 109, no. 40, pp. 16228-16233. http://dx.doi. org/10.1073/pnas.1207553109. PMid:22988106.

LI, C.R., XIA, W.S. and WANG, F.L., 2007. First record of Corythucha ciliata (Say) (Hemiptera:Tingidae), in China. Dong Wu Fen Lei Xue Bao, vol. 32, no. 4, pp. 944-946.

MONTE, O., 1941. Quatro novos Tingitídeos da América do Sul. Revista Brasileira de Biologia $=$. Brazilian Journal of Biology $=$ Revista Brasileira de Biologia, vol. 1, no. 4, pp. 373-378.

MOREIRA, D.C., REDAELLI, L.R., GUIDOTI, M. and BARCELLOS, A., 2013. Compared nymphal development of Tingis americana (Hemiptera, Tingidae) in two Handroanthus species (Bignoniaceae) and reproductive parameters in seedlings of Handroanthus heptaphyllus. Iheringia, vol. 103, no. 2, pp. 195-199. http://dx.doi.org/10.1590/S0073-47212013000200015.

NEAL JUNIOR, J.W. and DOUGLASS, L.W., 1988. Development, oviposition rate, longevity, and voltinism of Stephanitis pyrioides (Heteroptera: Tingidae), an adventive pest of azalea, at three temperatures. Environmental Entomology, vol. 17, no. 5, pp. 827-831. http://dx.doi.org/10.1093/ee/17.5.827.

NEAL JUNIOR, J.W. and DOUGLASS, L.W., 1990. Seasonal dynamics and the effect of temperature in Corythuch a cydoniae (Heteroptera: Tingidae). Environmental Entomology, vol. 19, no. 5, pp. 1299-1304. http://dx.doi.org/10.1093/ee/19.5.1299.

OVERGAARD, J., KEARNEY, M.R. and HOFFMANN, A.A., 2014. Sensitivity to thermal extremes in Australian Drosophila implies similar impacts of climate change on the distribution of widespread and tropical species. Global Change Biology, vol. 20 , no. 6, pp. 1738-1750. http://dx.doi.org/10.1111/gcb.12521. PMid:24549716.

PEREIRA, F.F., ZANUNCIO, J.C., OLIVEIRA, H.N., GRANCE, E.V., PASTORI, P.L. and GAVA-OLIVEIRA, M.D., 2011. Thermal requirements and estimate number of generations of Palmistichus elaeisis (Hymenoptera: Eulophidae) in different Eucalyptus plantations regions. Brazilian Journal of Biology $=$ Revista Brasileira de Biologia, vol. 71, no. 2, pp. 431-436. http:// dx.doi.org/10.1590/S1519-69842011000300012. PMid:21755160.

PONCIO, S., DEQUECH, S.T.B., BOLZAN, A., GÜTHS, C., WALKER, M.P., STURZA, V.S. and NAVA, D.E., 2016. Effect of temperature on immatures of Stiretrus decastigmus (Hemiptera: Pentatomidae). Brazilian Journal of Biology $=$ Revista Brasileira de Biologia, vol. 76, no. 2, pp. 495-499. http://dx.doi. org/10.1590/1519-6984.21914. PMid:26983086.

RIBEIRO JÚNIOR, J.I., 2001. Análises estatísticas no SAEG. Viçosa: UFV, $301 \mathrm{p}$

RIBEIRO, L.P. and COSTA, L.C., 2008. Ocorrência de Erinnyis ello e Spodoptera marina na cultura da mamona no Rio Grande do Sul. Ciência Rural, vol. 38, no. 8, pp. 2351-2353. http://dx.doi. org/10.1590/S0103-84782008000800040.

SÁNCHEZ-RAMOS, I., PASCUAL, S., FERNÁNDEZ, C.E., MARCOTEGUI, A. and GONZÁLEZ-NÚÑEZ, M., 2015. Effect of temperature on the survival and development of the immature stages of Monosteira unicostata (Hemiptera: Tingidae). European Journal of Entomology, vol. 112, no. 4, pp. 664-675. http://dx.doi. org/10.14411/eje.2015.087

SEVERINO, L.S., AULD, D.L., BALDANZI, M., CÂNDIDO, M.J.D., CHEN, G., CROSBY, W., TAN, D., HE, X., LAKSHMAMMA, P., LAVANYA, C., MACHADO, O.L.T., MIELKE, T., MILANI, 
M., MILLER, T.D., MORRIS, J.B., MORSE, S.A., NAVAS, A.A., SOARES, D.J., SOFIATTI, V., WANG, M.L., ZANOTTO, M.D. and ZIELER, H., 2012. A review on the challenges for increased production of castor. Agronomy Journal, vol. 104, no. 4, pp. 853880. http://dx.doi.org/10.2134/agronj2011.0210.

SILVA, C.A.D., 2004. Efeitos da temperatura no desenvolvimento, fecundidade e longevidade de Gargaphia torresi Lima (Hemiptera, Tingidae). Revista Brasileira de Entomologia, vol. 48, no. 4, pp. 547-552. http://dx.doi.org/10.1590/S0085-56262004000400018.

SOUTHWOOD, T.R.E., 1973. The insect/plant relationship an evolutionary perspective. In: H.F. VAN EMDEN, ed. Insect/plant relationships. London: Blackwell, pp. 3-30.

VARÓN, E.H., MOREIRA, M.D. and CORREDOR, J.P., 2010. Effect of Corythucha gossypii on castor oil plant leaves: Sampling criteria and control by insecticides. Corpoica Ciencia y Tecnología Agropecuaria, vol. 11, no. 1, pp. 41-47.

VOGT, T.E. and MCPHERSON, J.E., 1986. Life history and laboratory rearing of Corythuca juglandis (Hemiptera: Tingidae) with descriptions of immature stages. Great Lakes Entomologist, vol. 19, pp. 221-233.

WILSON, L.T. and BARNETT, W.W., 1983. Degree-day: an aid in crop and pest management. California Agriculture, vol. 37, no. 1, pp. 4-7.

ZHANG, Y., HANULA, J.L., HORN, S., BRAMAN, S.K. and SUN, J., 2011. Biology of Leptoypha hospita (Hemiptera: Tingidae), a potential biological control agent of Chinese Privet. Annals of the Entomological Society of America, vol. 104, no. 6, pp. 1327-1333. http://dx.doi.org/10.1603/AN11042. 